\title{
Studies of the Metabolic Activity of Leukocytes from Patients with a Genetic Abnormality of Phagocytic Function*
}

\author{
Bevlah Holmes, $\neq$ Arthur R. Page, $\S$ and Robert A. Good $\|$ \\ (From the Pediatrics Research Laboratories of the Varicty Club Heart Hospital and the \\ Departments of Pediatrics and Microbiology, University of Minnesota, \\ Minneapolis, Minnesota)
}

\begin{abstract}
Summary. Polymorphonuclear leukocytes from patients with chronic granulomatous disease respond to the phagocytosis of latex particles with normal increments in glucose consumption, lactate production, Krebs' cycle activity, and lipid turnover.

The leukocytes of these patients fail to show normal increments in respiration, direct oxidation of glucose, and hydrogen peroxide formation during particle uptake.

It appears that the stimulation of respiration with the formation of hydrogen peroxide and stimulation of the direct oxidative pathway of glucose metabolism are closely linked to degranulation and intracellular killing of bacteria by polymorphonuclear leukocytes.
\end{abstract}

\section{Introduction}

The study of the metabolic events accompanying phagocytosis of particles by polymorphonuclear leukocytes has been a subject of extensive investigation during the past several years. The most striking changes that occur in metabolism during particle uptake are considerable increases in oxygen consumption (1-4) and in the amount of glucose metabolized via the hexose monophosphate pathway $(4,5)$. There are less conspicuous increases in lactic acid production, glucose con-

* Submitted for publication 18 January 1967; accepted 5 June 1967.

Supported by the U. S. Public Health Service grants (AM-05830) (HE-06314), AI-00798 and The National Foundation.

Presented in part at the Sixth Annual Meeting, Society for Cell Biology, 1966.

$\ddagger$ Research Assistant, U. S. Public Health Service Training Grant in Medical Microbiology AI 90-06.

Address requests for reprints to Dr. Beulah Holmes, Department of Microbiology, University of Minnesota Medical School, Minneapolis, Minn. 55455.

$\S$ Associate Professor, Career Development Awardee of the U. S. Public Health Service.

II American Legion Memorial Heart Research Professor of Pediatrics and Microbiology. sumption (3, 4), and glycogen breakdown (3) during phagocytosis. The incorporation of radioactive precursors into lipid is increased although no net increase in total lipid is observed $(6,7)$. There is also a marked increase in formate oxidation after particle uptake, which is thought to reflect an increase in hydrogen peroxide formation (8).

It has been established that the inhibition of the glycolytic pathway of glucose metabolism by a metabolic inhibitor such as iodoacetate will also inhibit phagocytosis (2-4). In contrast, the inhibition of cytochrome-linked respiration, oxidative phosphorylation, or Krebs' cycle activity has no effect on the uptake of particles or the increase in respiration and direct oxidation of glucose that occurs during this process $(3,4,8)$. Glycolysis, therefore, appears to be essential to the process of phagocytosis. However, the cellular function of the increment in direct oxidation of glucose and respiration has not been established.

A chronic fatal granulomatous disease of childhood has been separated from the many granulomatous diseases of childhood and defined as a clinical entity by Berendes et al. (9) and Bridges 
et al. (10). This disease is characterized by apparent sex-linked inheritance, increased frequency of infections, chronic suppurative and granulomatous lymphadenitis, parenchymatous granulomatous infiltrations, and episodes of infected and eczematoid dermatitis. Similar cases and clinical definition of the syndrome have been reported by Landing and Shirkey (11) and Carson et al. (12).

The neutrophils from patients with this syndrome, have been shown to be defective in ability to kill some species of bacteria. However, their cells have been shown to phagocytize bacteria normally, and both light and electron microscopic studies during phagocytosis have revealed a lack of normal degranulation during particle uptake $(13,14)$. It has also been shown that granules from the leukocytes of these patients have normal amounts of acid phosphatase, beta glucuronidase, lysozyme, and phagocytin $(14,15)$. All available evidence indicates that the primary defects in these cells are a failure of degranulation and the release of bactericidal and digestive substances into the phagocytic vacuole. Apparently, this process is important in the intracellular killing of some organisms such as Staphylococcus aureus and Paracolon hafnia, whereas some other organisms such as streptococci are killed normally by these cells in spite of the degranulation defect (16).

The object of our investigation was to examine the metabolic events accompanying the phagocytosis of latex particles by leukocytes from patients with granulomatous disease. We found that these cells failed to show a normal increment in respiration, direct oxidation of glucose, and formate oxidation after the phagocytosis of particles. The results indicate that the increment in oxygen consumption, hexose monophosphate shunt activity, and production of hydrogen peroxide may be linked to normal degranulation after phagocytosis and to normal intracellular bactericidal activity.

\section{Methods}

Metabolic studies. In metabolic studies, the white blood cells were separated by sedimentation of heparinized venous blood in a solution of dextran in saline by the method used in the bactericidal studies (13). Differential counts on stained smears regularly revealed 80 $90 \%$ neutrophils.

The cells were isolated by centrifugation, washed, and resuspended in Krebs-Ringer phosphate medium
(KRP), $\mathrm{pH}$ 7.4. Polystyrene latex particles (Difco Laboratories, Inc., Detroit, Mich.) of $0.81 \mu$ diameter were used as the particles to be ingested in the metabolic experiments. With the exception of the respiration experiments, all determinations were made on duplicate samples incubated simultaneously with and without latex particles.

Oxygen consumption was measured in a biological oxygen monitor (Yellow Springs Instrument Company, Inc., Yellow Springs, Ohio, model 53). The total volume of fluid was $3 \mathrm{ml}$, and the total number of leukocytes varied from 15 to $60 \times 10^{6}$. Glucose was added to a final concentration of $5 \mathrm{mmoles} / \mathrm{liter}$. Suspensions were equilibrated to a constant temperature of $37^{\circ} \mathrm{C}$ for 5-10 min before beginning the readings. Addition of particles $(0.15 \mathrm{ml})$ was made by injection into the chamber with a $9 \mathrm{~cm}$ 21-gauge needle fitted to a tuberculin syringe. Air-dried smears were prepared after respiration experiments and were stained with Wright's stain.

Glucose metabolism and formate oxidation. Carbon-14 dioxide produced by oxidation of ${ }^{14} \mathrm{C}$-labeled substrates was absorbed on filter paper saturated with $20 \%$ sodium hydroxide and suspended from the stopper of a $15 \mathrm{ml}$ flask containing $5-20 \times 10^{8}$ cells in $1 \mathrm{ml} \mathrm{KRP}$ medium. The $1 \mathrm{ml}$ incubation mixture contained $1 \mu$ mole of glucose and $1 \mu \mathrm{c}$ of ${ }^{14} \mathrm{C}$ for glucose- $1{ }^{14} \mathrm{C}$ and glucose- $-6{ }^{14} \mathrm{C}$ experiments and $0.8 \mu \mathrm{c}$ of ${ }^{14} \mathrm{C}$ for glucose-3,4-14 $\mathrm{C}$ experiments. For experiments with added electron acceptors, cells were incubated in the presence of $3 \times 10^{-4}$ M methylene blue or $9 \times 10^{-3} \mathrm{M}$ sodium pyruvate. In the formate experiments, the $1 \mathrm{ml}$ incubation mixture contained $5 \mu$ moles of glucose and $3 \mu \mathrm{c}$ of formate ${ }^{14} \mathrm{C}(0.7$ $\mu$ mole). At the end of the incubation period, the stoppers were removed, and the filter paper was dried in air. The filter paper was placed in scintillation counting vials with $10 \mathrm{ml}$ of scintillation counting fluid [toluene containing $0.4 \%$ 2,5-diphenyloxazole (PPO) and $0.01 \%$ 1,4-bis [2-(5phenyloxazolyl] benzene (POPOP)] (Packard Instrument Co., Inc., Downers Grove, Ill.), and radioactivity was assayed in a Packard Tri-Carb scintillation counter. Radioactive substrates were obtained from New England Nuclear Corporation, (Boston, Mass.).

For the measurement of lactate production, glucose utilization, and glycogen breakdown, cell suspensions were incubated in Krebs-Ringer phosphate medium plus $1 \mathrm{~mm}$ glucose on a reciprocating water bath shaker at $37^{\circ} \mathrm{C}$. After $20 \mathrm{~min}$ incubation, samples were removed and deproteinized with perchloric acid $(0.05 \mathrm{ml} / \mathrm{ml}$ of reaction mixture) or pipetted directly into $\frac{1}{2}$ volume of $30 \%$ potassium hydroxide for glycogen analysis. After deproteinization, the suspension was centrifuged and the supernatant neutralized with $3 \mathrm{~N} \mathrm{KOH}$ or $5 \mathrm{M} \mathrm{K}_{2} \mathrm{CO}_{3}$ and analyzed for glucose and lactic acid concentration. Glucose was determined by the method of Mendel et al. (17). Glycogen determinations were performed by the technique of Siefter et al. (18). Lactic acid was determined by the method of Holzer and Soling (19). Zinc lactate or sodium lactate was used as a standard. The 
reactions were carried out in $1 \mathrm{ml}$ Beckman quartz cuvettes and in a solution of Tris buffer $(0.45 \mathrm{M}, \mathrm{pH} 9.5)$.

Lipid metabolism. In studies of lipid metabolism, cell suspensions in Krebs-Ringer phosphate medium plus 10 $\mathrm{mm}$ glucose were incubated with and without particles for $20 \mathrm{~min}$ at $37^{\circ} \mathrm{C}$ in the presence of acetate ${ }^{14} \mathrm{C}(10 \mu \mathrm{c} /$ $\mathrm{ml})$, phosphate- ${ }^{32} \mathrm{P}(96 \mu \mathrm{c} / \mathrm{ml})$ or uniformly labeled glu$\operatorname{cose}{ }^{14} \mathrm{C}(2.5 \mu \mathrm{c} / \mathrm{ml})$. At the end of the incubation period, the flasks were chilled and the contents transferred to a centrifuge tube or $12 \times 100 \mathrm{~mm}$ glass homogenizer. The cells were centrifuged at $150-200 \mathrm{~g}$ for $10 \mathrm{~min}$. The red blood cells were lysed by exposure to $0.0256 \mathrm{M}$ $\mathrm{NaCl}$ for $1 \mathrm{~min}$ and the addition of 2 volumes of $0.218 \mathrm{M}$ $\mathrm{NaCl}$. The cells were resedimented and washed with Krebs-Ringer phosphate medium. The sediment was extracted with chloroform-methanol $(2: 1)$ by the method of Folch et al. $(20,21)$; except that during the extraction the chloroform-methanol mixture was heated to the boiling point and then allowed to stand at room temperature for $30 \mathrm{~min}$ before filtering (22). To eliminate extraneous radioactive material, the chloroform-methanol mixture was washed five times with $\frac{1}{3}$ volume of theoretical upper phase containing $0.1 \%$ cold potassium phosphate, glucose, or sodium acetate. The extract was filtered into a $10 \mathrm{ml}$ volumetric flask. In experiments with labeled acetate and glucose, $1 \mathrm{ml}$ volumes of the extract were pipetted into counting vials. The solvent was evaporated under nitrogen and the lipid redissolved in $10 \mathrm{ml}$ of scintillation counting fluid. Radioactivity was determined in a Packard Tri-Carb liquid scintillation counter. The total lipid content was determined microgravimetrically. An aliquot of the solution was evaporated to dryness, resuspended in a small volume of chloroform, and trans- ferred to a tared foil planchet $(50-100 \mathrm{mg})$. The tube was washed three times with small volumes of chloroform to insure complete transfer. The solvent was evaporated under a heat lamp and the planchets were placed in a dessicator jar over $\mathrm{CaCl}_{2}$. After $24 \mathrm{hr}$, the planchets were weighed. In experiments with phosphate ${ }^{32} \mathrm{P}$, aliquots were removed from the $10 \mathrm{ml}$ volumetric flask for phosphorus analysis by the method of Lowry et al. (23). The reaction mixture from the phosphate determination was extracted with $4 \mathrm{ml}$ of isobutanol. The optical density of the isobutanol extract was measured in a Bausch \& Lomb Spectronic 20 (Bausch \& Lomb Incorporated, Rochester, N. Y.), and an aliquot was plated and counted in a gas flow counter. ${ }^{1}$

Column chromatography. Cell suspensions were incubated in Krebs-Ringer phosphate medium plus $5 \mathrm{~mm}$ glucose in the presence of $200 \mathrm{~mm}$ pyruvate- $2-{ }^{14} \mathrm{C}$ or sodium bicarbonate- ${ }^{14} \mathrm{C}(1 \mu \mathrm{c} / \mathrm{ml})$. After incubation for $20 \mathrm{~min}$ at $37^{\circ} \mathrm{C}$, the suspension was deproteinized with perchloric acid $(0.05 \mathrm{ml} / \mathrm{ml}$ of reaction mixture), centrifuged, and the supernatant solution frozen for later analysis of organic acids and amino acids. A sample was treated with dry ice to expel radioactive $\mathrm{CO}_{2}$ and neutralized with $4 \mathrm{~N} \mathrm{KOH}$. The supernatant solution was applied to a Dowex $1-8 \mathrm{X}\left(\mathrm{Cl}^{-}\right)$column, and fractions were collected and monitored for radioactivity through an anthracene flow counter. The tubes corresponding to each peak of radioactivity were combined and aliquots were neutralized and counted with a NuclearChicago D-47 gas flow counter. Peaks were separated

${ }^{1}$ Schafer, W., and M. L. Karnovsky. 1966. Unpublished data.

TABLE I

The effect of particle ingestion by leukocytes from granulomatosis patients on glucose consumption, lactate production, and glycogen content

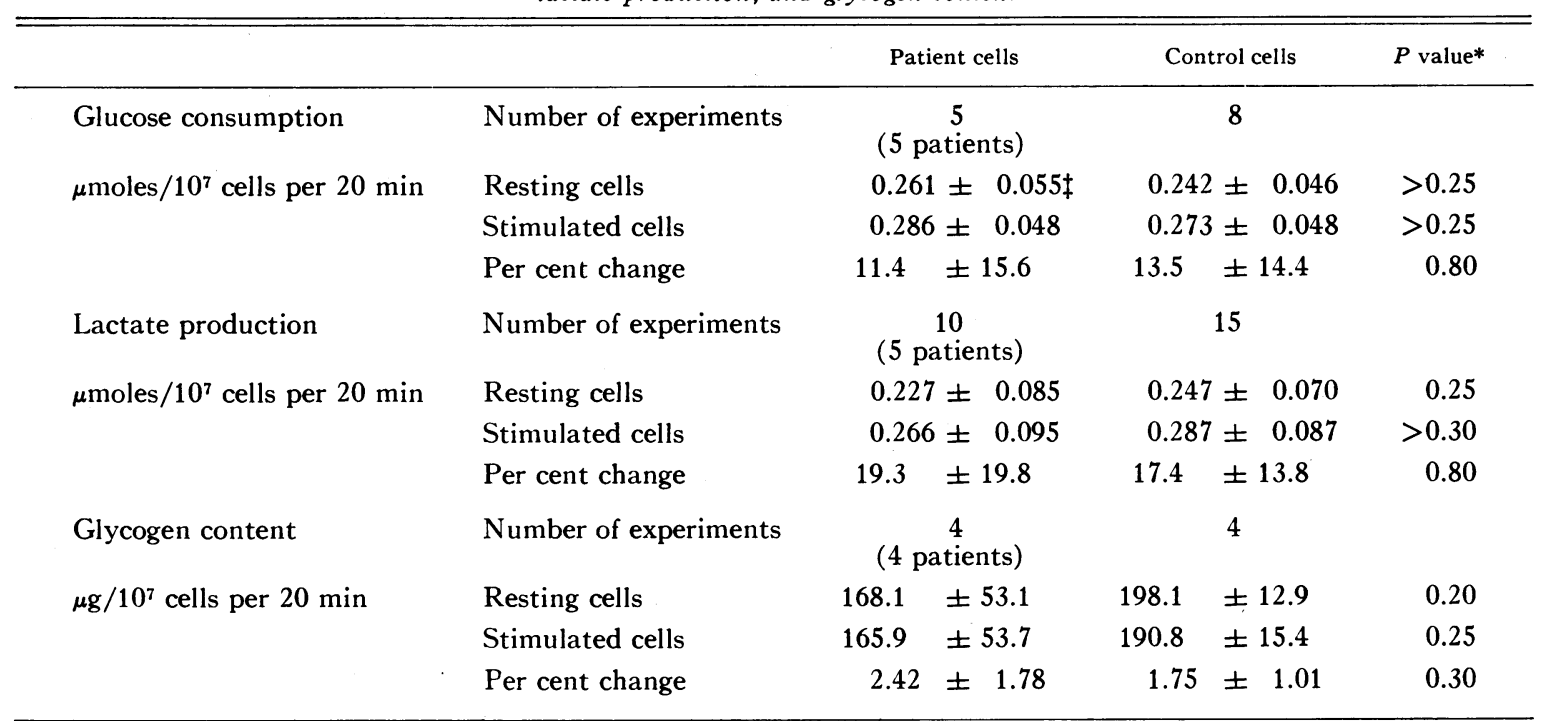

* $P$ is the probability value for differences between patient and control groups.

$\ddagger$ The mean and SD are given. 
TABLE II

Effect of particle ingestion on ${ }^{32} P$ and glucose- $U-{ }^{14} C$ incorporation into leukocyte lipid

\begin{tabular}{|c|c|c|c|c|c|}
\hline & & $\begin{array}{l}\text { Patient } \\
\text { cells }\end{array}$ & Mean & $\begin{array}{l}\text { Control } \\
\text { cells }\end{array}$ & Mean \\
\hline \multirow{4}{*}{$\begin{array}{l}\text { Incorporation of }{ }^{32} \mathrm{P} \text { into lipid } \\
\mathrm{cpm} / \mu \mathrm{g} \mathrm{P}\end{array}$} & Number of experiments & 2 & & 2 & \\
\hline & Resting cells & $\begin{array}{l}42.9 \\
57.7\end{array}$ & 50.3 & $\begin{array}{l}51.5 \\
42.8\end{array}$ & 47.1 \\
\hline & Stimulated cells & $\begin{array}{l}61.6 \\
82.5\end{array}$ & 72.1 & $\begin{array}{l}89.3 \\
54.7\end{array}$ & 72.0 \\
\hline & Per cent change & $\begin{array}{l}43.0 \\
42.0\end{array}$ & 42.5 & $\begin{array}{l}73.0 \\
27.0\end{array}$ & 50.0 \\
\hline \multirow{4}{*}{$\begin{array}{l}\text { Incorporation of glucose- } \mathrm{U}_{-}{ }^{14} \mathrm{C} \\
\text { into lipid } \\
\mathrm{cpm} / \mathrm{mg} \text { lipid }\end{array}$} & Number of experiments & 2 & & 3 & \\
\hline & Resting cells & $\begin{array}{r}80.5 \\
184.7\end{array}$ & 132.6 & $\begin{array}{l}155.5 \\
109.8 \\
108.6\end{array}$ & 124.6 \\
\hline & Stimulated cells & $\begin{array}{l}129.3 \\
295.4\end{array}$ & 212.4 & $\begin{array}{l}262.1 \\
173.6 \\
138.6\end{array}$ & 191.4 \\
\hline & Per cent change & $\begin{array}{l}60.5 \\
59.9\end{array}$ & 60.2 & $\begin{array}{l}68.6 \\
58.1 \\
27.5\end{array}$ & 53.0 \\
\hline
\end{tabular}

into organic acids and amino acids on a Dowex 50 column. Organic acids were identified by silicic acid chromatography and amino acids were identified by chromatography on Dowex 50-X8 (24-26).

$N A D P H$ and $N A D H$ oxidase activity. Leukocytes were disrupted and fractionated by the method of Evans and Karnovsky (27). All steps in the procedure were performed at $0-5^{\circ} \mathrm{C}$. The leukocyte suspension was washed two times in cold saline and the red blood cells lysed by the procedure previously described. The sediment was suspended in $2 \mathrm{ml}$ of alkaline isotonic $\mathrm{KCl}$ $\left(0.15 \mathrm{M} \mathrm{KCl}\right.$ and $\left.3.2 \times 10^{-4} \mathrm{M} \mathrm{KHCO}_{3}\right)$ and disrupted in a glass homogenizer with motor-driven Teflon pestle. The homogenate was centrifuged at $240 \mathrm{~g}$ for $5 \mathrm{~min}$ and the supernatant decanted. The sediment was rehomogenized in $1 \mathrm{ml}$ of alkaline $\mathrm{KCl}$ and centrifuged again at $240 \mathrm{~g}$. The combined supernatants were used as the granule-rich fraction, and a granule-free fraction was obtained by additional centrifugation at $20,000 \mathrm{~g}$ for 30 min. NADH and NADPH oxidase assays were performed on one or the other of the two supernatant fractions obtained from the homogenate by centrifugation. Oxygen uptake was measured with a 2.5 or $3.0 \mathrm{ml}$ volume in medium containing $1.5 \mathrm{~mm} \mathrm{NADH}$ or NADPH in the presence of $1 \mathrm{~mm} \mathrm{KCN}$. The protein content of the reaction mixture was estimated using Folin-Ciocalteau reagent $(28)$.

\section{Results}

The effect of particle ingestion on glycolysis, lipid turnover, and Krebs' cycle activity. Glucose consumption and lactate production were measured after $20 \mathrm{~min}$ of incubation with or without latex particles using cells from five patients and eight controls.

The resting and stimulated rates for both glucose consumption and lactate production did not differ significantly when the patient cells were compared with control cells. These results are summarized in Table I.

Little or no breakdown of glycogen due to particle ingestion was detected in either the patient or the control group (Table I).

The extent of incorporation of phosphate- ${ }^{32} \mathrm{P}$ and glucose- ${ }^{14} \mathrm{C}$ into lipid of resting and phagocytizing leukocytes is shown in Table II. A marked stimulation of incorporation of both phosphate ${ }^{32} \mathrm{P}$ and uniformly labeled glucose- ${ }^{14} \mathrm{C}$ was observed in phagocytizing cells as compared with resting cells. This was true with leukocytes from normal controls and from patients with chronic granulomatous disease.

No increase in incorporation of acetate $-1-{ }^{14} \mathrm{C}$ into lipid of normal leukocytes during phagocytosis was detected in our experiments.

Studies on the regulation of carbohydrate, lipid, and glycogen metabolism have pointed to an important role of Krebs' cycle intermediate levels (29). Even though Krebs' cycle activity is low in normal neutrophils (PMN's) (30), it seemed possible that a metabolic block in the Krebs' cycle of leukocytes from patients with granulomatous 
TABLE III

The effect of particle ingestion by leukocytes from granulomatosis patients on oxygen consumption, and ${ }^{14} \mathrm{CO}_{2}$ production from glucose $-1-{ }^{14} C,-6-{ }^{14} C, 3,4-{ }^{14} C$, and formate $-{ }^{14} C$

\begin{tabular}{|c|c|c|c|c|c|c|c|}
\hline & & \multicolumn{2}{|c|}{ Patient cells } & \multicolumn{3}{|c|}{ Control cells } & $P$ value* \\
\hline Oxygen consumption & Number of experiments & \multicolumn{2}{|c|}{$\begin{array}{c}29 \\
\text { (6 patients) }\end{array}$} & \multicolumn{3}{|c|}{18} & \\
\hline \multirow{3}{*}{$\mu 1 \mathrm{O}_{2} / 10^{7}$ cells per $\mathrm{hr}$} & Resting cells & & $4 \pm \quad 7.0 \ddagger$ & & \pm & 3.8 & $<0.05$ \\
\hline & Stimulated cells & & $4 \pm \quad 8.2$ & & \pm & 22.5 & $<0.001$ \\
\hline & Per cent change & & $7 \pm 51.5$ & 520 & \pm & 463 & $<0.001$ \\
\hline $\begin{array}{l}{ }^{14} \mathrm{CO}_{2} \text { production from } \\
\text { glucose }-1-{ }^{-14} \mathrm{C}\end{array}$ & Number of experiments & \multicolumn{2}{|c|}{$\begin{array}{c}6 \\
\text { (5 patients) }\end{array}$} & \multicolumn{3}{|c|}{7} & \\
\hline \multirow[t]{3}{*}{$\mathrm{cpm} / 10^{7}$ cells per $20 \mathrm{~min}$} & Resting cells & 425 & \pm 414 & 1436 & \pm & 814 & 0.01 \\
\hline & Stimulated cells & 964 & \pm 268 & 19578 & \pm & 6293 & $<0.001$ \\
\hline & Per cent change & 140 & \pm 61 & 1157 & \pm & 604 & $<0.001$ \\
\hline $\begin{array}{l}{ }^{14} \mathrm{CO}_{2} \text { production from } \\
\text { glucose- } 6-{ }^{-14} \mathrm{C}\end{array}$ & Number of experiments & \multicolumn{2}{|c|}{$\begin{array}{c}5 \\
\text { (5 patients) }\end{array}$} & \multicolumn{3}{|c|}{6} & \\
\hline \multirow[t]{3}{*}{$\mathrm{cpm} / 10^{7}$ cells per $20 \mathrm{~min}$} & Resting cells & 15 & \pm 8.5 & 89 & \pm & 125 & 0.1 \\
\hline & Stimulated cells & 27 & \pm 18 & 180 & \pm & 71 & $<0.01$ \\
\hline & Per cent change & 88 & \pm 58 & 295 & \pm & 204 & $<0.05$ \\
\hline $\begin{array}{l}{ }^{14} \mathrm{CO}_{2} \text { production from } \\
\text { glucose- } 3,4-{ }^{-14} \mathrm{C}\end{array}$ & Number of experiments & \multicolumn{2}{|c|}{$\begin{array}{c}7 \\
\text { (5 patients) }\end{array}$} & \multicolumn{3}{|c|}{7} & \\
\hline \multirow{3}{*}{$\mathrm{cpm} / 10^{7}$ cells per $15 \mathrm{~min}$} & Resting cells & 116 & \pm 63 & 51 & \pm & 18 & $<0.05$ \\
\hline & Stimulated cells & 160 & \pm 58 & 179 & \pm & 126 & 0.25 \\
\hline & Per cent change & 57 & \pm 39 & 270 & \pm & 126 & $<0.05$ \\
\hline $\begin{array}{l}{ }^{14} \mathrm{CO}_{2} \text { production from } \\
\text { formate- }{ }^{-14} \mathrm{C}\end{array}$ & Number of experiments & \multicolumn{2}{|c|}{$\begin{array}{c}10 \\
(6 \text { patients })\end{array}$} & \multicolumn{3}{|c|}{10} & \\
\hline \multirow[t]{3}{*}{ cpm $/ 10^{7}$ cells per $20 \mathrm{~min}$} & Resting cells & 643 & \pm 763 & 1077 & \pm & 1165 & 0.25 \\
\hline & Stimulated cells & 725 & \pm 826 & 2674 & \pm & 1941 & $<0.005$ \\
\hline & Per cent change & 25 & \pm 63 & 196 & \pm & 84 & $<0.001$ \\
\hline
\end{tabular}

* $P$ is the probability value for differences between patient and control groups.

$\ddagger$ The mean and SD are given.

disease might lead to a further derangement in metabolism. We, therefore, carried out an investigation of the pattern of ${ }^{14} \mathrm{CO}_{2}$ fixation and pyruvate- $2-{ }^{14} \mathrm{C}$ incorporation into Krebs' cycle intermediates and amino acids by leukocytes from patients and normal controls.

In studies of $\mathrm{CO}_{2}$ fixation, samples from the incubation of cells with and without particles in the presence of sodium bicarbonate- ${ }^{14} \mathrm{C}$ were applied to Dowex $1-8 \mathrm{X}$ columns. In samples from normal resting leukocytes, the major peak of radioactivity corresponded to the position of elution of lactic acid, acetic acid, glutamic acid, and aspartic acid. The other notable peaks of radioactivity corresponded to alanine and succinic acid.

When the major radioactive peak was separated into organic acids and amino acids on Dowex 50, roughly $60 \%$ of the radioactivity was found in the organic acid fraction. The amino acids were identified on Dowex 50-X8. Aspartic acid comprised about $35 \%$ of the radioactivity and glutamic acid was the major component as determined by relative weights of the peak areas on the chart. The components of the organic acid fraction were identified by silicic acid chromatography. The major component of this fraction was lactic acid, with traces of acetic acid and succinic acid.

Chromatography of samples from normal controls did not reveal a difference in pattern of incorporation of radioactivity due to phagocytosis. However, an increase of from $25-30 \%$ in incorporation was found to take place.

Samples from the incubation of leukocytes from patients with chronic granulomatous disease were 
very similar in pattern of incorporation to samples from normal controls. The increase in radioactivity of samples from phagocytizing leukocytes of patients was of the same order as controls.

In studies of the incorporation of pyruvate- $2-{ }^{14} \mathrm{C}$ into Krebs' cycle intermediates and amino acids, identical results were obtained, although the extent of incorporation was greater.

The effect of particle ingestion on respiration and oxidation of specifically labeled glucose. The extent of increase in oxygen consumption by leukocyte suspensions from patients with chronic granulomatous disease and normal controls incubated in the presence of latex particles is shown in Table III. Patients with granulomatous disease have consistently failed to show the normal respiratory increment during particle uptake. Although values for oxygen uptake in controls varied greatly, a significant increase in oxygen consumption was observed in every experiment. On a few occasions, leukocytes from patients with granulomatous disease exhibited a respiratory increment during phagocytosis. However, the increase in the amount of oxygen consumed during phagocytosis by leukocytes from patients was significantly lower than that observed with normal controls $(P$ value was less than 0.001$)$. Stained smears prepared after cells were incubated with latex particles in the respiration experiments revealed no difference in particle uptake between leukocytes of patients and controls.

A comparison of the pattern of ${ }^{14} \mathrm{CO}_{2}$ production from glucose- $1-{ }^{14} \mathrm{C}$ and glucose- $6-{ }^{14} \mathrm{C}$ by leukocytes incubated with and without latex particles is shown in Table III. The resting level of ${ }^{14} \mathrm{CO}_{2}$ production from glucose- $1-{ }^{14} \mathrm{C}$ was significantly lower in the leukocytes of patients, and the patients' cells failed to show stimulation of $\mathrm{C}-1$ oxidation during phagocytosis. The average per cent increase during phagocytosis was 140 in the patients' cells as compared to 1157 in the control cells $(P<0.001)$.

Resting values for ${ }^{14} \mathrm{CO}_{2}$ production from glucose- $-{ }^{-14} \mathrm{C}$ were normal in the patients' cells. There was less stimulation of C- 6 oxidation during phagocytosis in the patients' cells. However, because of the low level of C- 6 oxidation in normal leukocytes and because of a high blank value for the evolution of ${ }^{14} \mathrm{CO}_{2}$ from the glucose- $6-{ }^{14} \mathrm{C}$ used, these data are extremely variable and the only reliable conclusion is that the patients' cells, like the normal cells, have low levels of C-6 oxidation.

In addition, leukocytes from patients did not show the normal increment in ${ }^{14} \mathrm{CO}_{2}$ formation from glucose-3,4-14 $\mathrm{C}$ during phagocytosis. The stimulation of carbon-14 dioxide formation from glucose-3,4-14 $\mathrm{C}$ was at least twofold higher in leukocytes from controls than from patients. However, the resting rate of the patients' cells was higher than normal. These results are summarized in Table III.

The effect of particle ingestion on hydrogen peroxide formation. Iyer et al. (8) have shown that hydrogen peroxide is formed in guinea pig polymorphonuclear leukocytes during phagocytosis. In their experiments, hydrogen peroxide produced was estimated by measuring the oxidation of formate. Chance has shown that in the presence of peroxidase or catalase, hydrogen peroxide oxidizes formate (31). It is also known that leukocytes are rich in peroxidase (32), and the direct measurement of $\mathrm{H}_{2} \mathrm{O}_{2}$ by fluorometric assay shows a 2 - to 4 -fold increase during phagocytosis (33). The close correspondence between the increase in $\mathrm{H}_{2} \mathrm{O}_{2}$ as measured by fluorometric assay and formate oxidation seems sufficient evidence for utilizing formate oxidation as a relative measure of $\mathrm{H}_{2} \mathrm{O}_{2}$ production. The production of radioactive $\mathrm{CO}_{2}$ from $\mathrm{C}-14$ formate by resting leukocytes was compared to that from leukocytes incubated with latex particles (Table III). Normal cells incubated with particles oxidized from two to four times more formate than did normal resting cells. In contrast, leukocytes from patients with granulomatous disease did not demonstrate any increase in formate oxidation during phagocytosis in the majority of experiments. This difference was highly significant $(P<$ $0.001)$.

Effect of electron acceptors on conversion of glucose-1 $-{ }^{14} \mathrm{C}$ to ${ }^{14} \mathrm{CO}_{2}$. Since leukocytes from patients with chronic granulomatous disease have abnormally low hexose monophosphate shunt activity as measured by oxidation of glucose- $-1{ }^{14} \mathrm{C}$, experiments were performed in an effort to further define the basis of the abnormality. These results could be the result of an enzymatic defect in the hexose monophosphate pathway or of a lack of sufficient NADP, since it has been shown that 
TABLE IV

Effect of electron acceptors on conversion of glucose-1-14 $\mathrm{C}$ to ${ }^{14} \mathrm{CO}_{2}$

\begin{tabular}{|c|c|c|c|c|}
\hline & \multicolumn{2}{|c|}{ Patient cells } & \multicolumn{2}{|c|}{ Control cells } \\
\hline & $\begin{array}{c}\text { Activity in } \mathrm{CO}_{2} \\
\text { (cpm) } \\
\text { (3 experiments) }\end{array}$ & Per cent change & $\begin{array}{c}\text { Activity in } \mathrm{CO}_{2} \\
\quad(\mathrm{cpm}) \\
\text { (4 experiments) }\end{array}$ & Per cent change \\
\hline $\begin{array}{l}\text { No addition } \\
\text { Methylene blue } \\
\text { Pyruvate }\end{array}$ & $\begin{array}{r}44.0 \pm 10.0^{*} \\
1458.0 \pm 184 \\
239.0 \pm 37\end{array}$ & $\begin{aligned} 3251.5 & \pm 336.0 \\
448.0 & \pm 40.0\end{aligned}$ & $\begin{aligned} 392.8 & \pm 75.0 \\
1586.0 & \pm 436.0 \\
524.5 & \pm 136.0\end{aligned}$ & $\begin{array}{r}315 \pm 130 \\
34.3 \pm 25\end{array}$ \\
\hline
\end{tabular}

* The mean and SD are given.

the hexose monophosphate pathway is limited by the amount of available NADP (34).

It has been shown that pyruvate and methylene blue will stimulate $\mathrm{C}-1$ glucose oxidation by oxidizing NADPH $(23,35,36)$. Therefore, the effect of these electron acceptors on glucose- $1-{ }^{14} \mathrm{C}$ oxidation in the leukocytes of these patients was studied. As shown in Table IV, both pyruvate and methylene blue stimulated oxidation of $\mathrm{C}-1$ glucose normally in the cells from these patients. These results indicate that the enzymes of the hexose monophosphate pathway are normal and that the limiting factor is a lack of sufficient oxidized NADP.

NADPH and NADH oxidase activities of leukocyte homogenates. The importance of a cyanide insensitive NADPH and/or NADH link to oxygen has been implicated in relation to the respiratory increment due to phagocytosis $(8,37)$. The failure of leukocytes from patients with chronic granulomatous disease to show a normal respiratory response or increase in hexose monophosphate shunt activity during phagocytosis suggested the possibility that NADPH or NADH oxidase is lacking or deficient in these cells.

The results of an investigation of the oxidase activity of leukocyte homogenates are shown in Table V. Similar levels of cyanide-insensitive
$\mathrm{NADPH}$ and $\mathrm{NADH}$ oxidase activity were found in the granule fraction (240 g supernatant) of leukocytes from patients as compared to controls.

In one experiment, slight $\mathrm{NADH}$ oxidase activity was present in the supernatant from the $20,000 \mathrm{~g}$ centrifugation. There was no difference between patient and control. It seems possible that this low level of supernatant NADH oxidase is the result of contamination of the fraction by ruptured granules.

\section{Discussion}

Leukocytes from patients with chronic granulomatous disease have previously been shown to be defective in their ability to kill certain types of bacteria $(13,14)$. Leukocytes from these patients phagocytize bacteria normally, but fail to kill intracellular bacteria apparently because the lysosomal granules do not rupture and empty their contents into the phagocytic vacuole.

The present study of the metabolism of leukocytes from these patients has shown that glucose utilization, lactate production, Krebs' cycle activity, and lipid turnover are all stimulated normally during phagocytosis. However, leukocytes from these patients fail to show a normal stimulation of respiration, hydrogen peroxide production,

TABLE $\mathrm{V}$

Cyanide resistant NADH and NADPH oxidase activity in leukocyte homogenates

\begin{tabular}{|c|c|c|c|}
\hline & $\begin{array}{c}\text { Patient cells } \\
\text { (3 experiments) }\end{array}$ & $\begin{array}{c}\text { Control cells } \\
\text { (4 experiments) }\end{array}$ & $P$ value* \\
\hline NADPH oxidase & $1.20 \pm 0.18 \ddagger$ & $1.46 \pm 0.53$ & 0.25 \\
\hline $\begin{array}{l}\mu \mathrm{O}_{2} \text { consumed } / \mathrm{mg} \text { protein } \text { per } \mathrm{hr} \\
\mathrm{NADH} \text { oxidase } \\
\mu \mathrm{O}_{2} \text { consumed } / \mathrm{mg} \text { protein per } \mathrm{hr}\end{array}$ & $0.97 \pm 0.45$ & $0.85 \pm 0.21$ & 0.30 \\
\hline
\end{tabular}

${ }^{*} P$ is the probability value for differences beween pattient and control groups.

$\ddagger$ The mean and SD are given. 
and hexose monophosphate pathway (HMP) activity. It seems reasonable to assume that these metabolic abnormalities are intimately associated with the failure of degranulation and the subsequent failure of intracellular killing of bacteria.

Although the stimulation of respiration and HMP activity always accompanies phagocytosis in normal cells, there is an increasing amount of evidence which indicates that these metabolic events are not essential to the process of phagocytosis. When neutrophils are incubated anaerobically, they phagocytize normally but fail to show stimulation of respiration, HMP activity, or formate oxidation $(4,8,38)$, and at the same time they have a bactericidal defect (39). Colchicine treated neutrophils will phagocytize bacteria normally but fail to show normal degranulation (40) and show a bacterial killing defect ${ }^{2}$ similar to that seen in cells from granulomatosis patients. Colchicine treated cells also fail to show a stimulation of respiration (40) and HMP activity during phagocytosis. $^{3}$ Sodium fluoride prevents phagocytosis by blocking glycolysis and at the same time causes intracellular degranulation and stimulation of both respiration and HMP shunt activity (39).

These results and the results of our studies on leukocytes from patients with chronic granulomatous disease are consistent with a separation of the metabolic events accompanying phagocytosis into two categories: $(a)$ the metabolic events associated with particle uptake, including stimulation of glucose utilization, lactate production, and lipid turnover, and $(b)$ the metabolic events associated with degranulation, including stimulation of respiration, hydrogen peroxide production, and HMP activity.

The metabolic basis for degranulation and subsequent intracellular digestion of particles by leukocytes is unknown. Karnovsky (41) and Rowley (42) have suggested that the accumulation of lactic acid is the stimulus to degranulation. The results of the metabolic study of leukocytes from our patients with granulomatous disease would indicate that lactate may not initiate the process of degranulation as proposed, since lactic acid production by white blood cells of our patients is normal, and yet degranulation does not take place.

\footnotetext{
${ }^{2}$ Kaplan, E. L., P. G. Quie, and D. B. Windhorst. Personal communication.

3 Page, A. R. Unpublished data.
}

Although it seems clear that the stimulation of respiration and HMP activity are associated with degranulation, it is not possible to determine from the information presently available whether the metabolic stimulation is primary or secondary to the process of degranulation.

The fact that leukocytes from patients with chronic granulomatous disease have abnormally low HMP activity in the resting state indicates that an enzymatic abnormality associated with regulation of this pathway may be the primary defect. Beck has shown that the availability of oxidized NADP is a limiting factor in regulating HMP activity in human leukocytes (34). It seems likely that an abnormality in a pathway for the oxidation of NADP exists in the leukocytes of granulomatosis patients. The demonstrated stimulation of the HMP activity with methylene blue and pyruvate indicates that these cells have adequate supplies of NADPH and also that the hexose monophosphate pathway will operate when NADP is made available.

Several groups of investigators have been interested in the metabolic mechanism for linking the stimulation of respiration to the stimulation of HMP activity. Iyer and Quastel (43) and Roberts and Quastel (44) have found that the homogenate of guinea pig polymorphonuclear cells contains an enzyme system capable of oxidizing $\mathrm{NADPH}$ and $\mathrm{NADH}$ in the presence of oxygen to form hydrogen peroxide. The enzyme is more active towards NADPH than NADH. Rossi and Zatti $(45,46)$ have found a granule-associated $\mathrm{NADH}$ and NADPH oxidase which increases dramatically during phagocytosis and which is also more active towards NADPH. Both groups of investigators believe that the NADPH oxidase is directly responsible for the stimulation in respiration and peroxide formation by the utilization of molecular oxygen to oxidize NADPH with the formation of peroxide and NADP. The NADP would then be available to stimulate hexose monophosphate shunt activity.

Evans and Karnovsky (47) have proposed that the stimulation of respiration is due to an activation of a cytoplasmic NADH oxidase that uses molecular oxygen to oxidize NADH. They have shown that leukocytes contain a lactic dehydrogenase that will utilize NADPH to reduce pyruvate to lactate. They postulate that the activation of 
the NADH oxidase results in depletion of cellular $\mathrm{NADH}$ and, therefore, increased utilization of NADPH by lactic dehydrogenase. The NADP produced in this reaction would then be the source of the stimulation of the HMP. Cagan and Karnovsky (37) have isolated a cytoplasmic enzyme that has specific NADH oxidase activity.

Because the respiratory increment seen in normal leukocytes during phagocytosis is not inhibited by $1 \mathrm{~mm}$ cyanide, it is important to know if the enzymes believed to be responsible. for the respiratory increment are also cyanide resistant. Cagan's purified NADH oxidase proved to be resistant to cyanide (37). This criterion has not yet been fulfilled for a purified NADPH oxidase, although the NADPH oxidase activity of the granule fraction has been shown to be partially cyanide resistant (46) as has the NADPH oxidase of Roberts and Quastel (44).

Although the absence of either NADH or NADPH oxidase activity would explain the metabolic defect in the neutrophils of the granulomatosis patients, we were unable to show any such deficiency. In our studies of leukocyte homogenates containing both the granules and the cytoplasm of the patients' neutrophils, we found cyanide-resistant NADH and NADPH oxidase activity equal to that found in normal cells. In an experiment using a granule-free cytoplasmic fraction, we found small amounts of NADH oxidase activity in normal cells and in the cells from one patient. Although our studies are not extensive enough to rule out the possibility of a deficiency of a cytoplasmic NADH oxidase as the cause of the leukocyte defect, they do nothing to encourage belief in this possibility.

Recently, Baehner and Nathan (48) have shown that normal neutrophils reduce tetrazolium dye at a rapid rate during phagocytosis whereas cells from patients with granulomatous disease fail to show significant dye reduction. They also have shown that the HMP of cells from these patients is not stimulated by phagocytosis but is stimulated by methylene blue. They interpret these results as showng a lack of cytoplasmic $\mathrm{NADH}$ oxidase activity, an assumption that is not warranted from the data they present, since the method they used gives no indication of either the source of the hydrogen ion or the type of intermediate electron acceptors responsible for the tetrazolium dye reduction in the normal cell.

The results of our study do not permit the definition of the precise enzymatic basis of the metabolic derangement of leukocytes from our patients. Windhorst et al. $(49,50)$, have recently studied the leukocytes of the members of eight families of children with chronic granulomatous disease. It was demonstrated that the leukocytes of all eight mothers and several sisters were intermediate in bactericidal capacity and tetrazolium reduction between leukocytes of affected boys and controls. This demonstration of female carriers indicates the sex-linked character of chronic granulomatous disease and adds considerable weight to the earlier suggestion that chronic granulomatous disease is inherited in a sex-linked manner (10, 12). These genetic data are certainly a sound indication that a single enzyme is lacking or deficient in the leukocytes of patients with this disease.

Whatever the enzyme lacking in these children and responsible in normal persons for degranulation and efficient killing of certain microorganisms, it is clear from studies of this strange genetic disorder that the metabolic changes associated with phagocytosis can be separated from the metabolic changes associated with degranulation of neutrophils and the subsequent killing of certain microorganisms. The functional defect and the associated metabolic abnormalities of the neutrophils are probably adequate to account for the increased susceptibility to infections with certain low grade pyogenic pathogens and the development of the disseminated granulomatosis seen in these children.

\section{Acknowledgments}

We would like to thank Dr. Robert Cagan, Dr. Manfred Karnovsky, and Dr. Richard Von Korff for valuable adyice in the planning of these studies. We also thank Dr. Richard Von Korff for making his laboratory available to us for the column chromatography studies.

\section{References}

1. Baldrige, C. W., and R. W. Gerard. 1933. The extra respiration of phagocytosis. Am. J. Physiol. 103: 235 .

2. Becker, H., G. Munder, and H. Fischer. 1958. Uber den Leukocytenstoffweeksel bei der Phagocytose. Hoppe-Seyler's Z. Physiol. Chem. 313, 266. 
3. Cohn, Z. A., and S. I. Morse. 1960. Functional and metabolic properties of polymorphonuclear leukocytes. I. Observations on the requirements and consequences of particle ingestion. J. Exptl. Med. $111: 667$.

4. Sbarra, A. J., and M. L. Karnovsky. 1959. The biochemical basis of phagocytosis. I. Metabolic changes during the ingestion of particles by polymorphonuclear leukocytes. J. Biol. Chem. $234: 1355$.

5. Stahelin, H., M. L. Karnovsky, A. E. Farnham, and E. Suter. 1957. Studies on the interaction between phagocytes and tubercle bacilli. III. Some metabolic effects in guinea pigs associated with injection with tubercle bacilli. J. Exptl. Med. 105 : 265.

6. Sbarra, A. J., and M. L. Karnovsky. 1960. The biochemical basis of phagocytosis. II. Incorporation of $\mathrm{C}^{\mathbf{1 4}}$-labeled building blocks into lipid, protein, and glycogen of leukocytes during phagocytosis. J. Biol. Chem. 235 : 2224.

7. Elsbach, P. 1959. Composition and synthesis of lipids in resting and phagocytizing leukocytes. J. Exptl. Med. 110: 969.

8. Iyer, G. Y. N., M. F. Islam, and J. H. Quastel. 1961. Biochemical aspects of phagocytosis. $\mathrm{Na}$ ture. $192: 535$.

9. Berendes, H., R. A. Bridges, and R. A. Good. 1957. A fatal granulomatosis of childhood: The clinical study of a new syndrome. Minn. Med. 40: 309.

10. Bridges, R. A., H. Berendes, and R. A. Good. 1959. A fatal granulomatous disease of childhood. Am. J. Diseases Children. 97: 387.

11. Landing, B. H., and H. S. Shirkey. 1957. A syndrome of recurrent infection and infiltration of viscera by pigmented lipid histiocytes. Pediatrics. $20: 431$.

12. Carson, M. J., D. L. Chadwick, C. A. Brubaker, R. S. Cleland, and B. H. Landing. 1965. Thirteen boys with progressive septic granulomatosis. Pediatrics. 35 : 405.

13. Holmes, B., P. G. Quie, D. B. Windhorst, and R. A. Good. 1966. Fatal granulomatous disease of childhood: An inborn abnormality of phagocytic function. Lancet. $1: 1225$.

14. Quie, P. G., J. G. White, B. Holmes, and R. A. Good. 1967. In vitro Bactericidal capacity of human polymorphonuclear leukocytes: Diminished activity in chronic granulomatous disease of childhood. J. Clin. Invest. 46: 668.

15. Holmes, B. 1966. Studies on the Metabolic Activity of Leukocytes from Patients with a Genetic Abnormality of Phagocytic Function. Ph.D. thesis. University of Minnesota, Minneapolis.

16. Kaplan, E. L., T. Laxdal, R. Messner, and P. G. Quie. 1967. Bacterial specificity of a polymorphonuclear leukocyte defect in chronic granulomatous disease. Bact. Proc. 92. (Abstr.)
17. Mende1, B., A. Kemp, and D. K. Myeres. 1954. A colorimetric micromethod for the determination of glucose. Biochem. J. 56: 639.

18. Seifter, S., S. Dayton, B. Novic, and E. Muntivyler. 1950. The estimation of glycogen with the anthrone reagent. Arch. Biochem. Biophys. 25: 191.

19. Holzer, H., and H. Soling. 1965. Determination of lactic acid with lactic dehydrogenase and the 3-acetylpyridine analogue of DPN (AP-DPN). In Methods of Enzymatic Analysis. H. U. Bergmeyer, editor. Academic Press, Inc., New York, 275.

20. Folch, J., M. Lees, and G. H. Sloane Stanley. 1957. A simple method for the isolation and purification of total lipids from animal tissues. J. Biol. Chem. 226 : 497

21. Folch, J., I. Ascoli, M. Lees, J. A. Meath, and F. N. Le Baron. 1951. Preparation of lipid extracts from brain tissue. J. Biol. Chem. 191: 833.

22. Sperry, W. M. 1955. Lipide Analysis. Methods of Biochem. Analy. 2 : 83.

23. Lowry, O. H., N. R. Roberts, K. Y. Leiner, M. L. $\mathrm{Wu}$, and A. L. Farr. 1954. The quantitative histochemistry of brain. I. Chemical methods. J. Biol. Chem. 207 : 1.

24. Bauer, C. A. 1966. Respiratory Control Ratio, Endogenous substrate and the Nature of Substrate Metabolism by Heart Muscle Mitochondria of Several Species. Master's thesis. University of Minnesota, Minneapolis.

25. Kinnory, D. S., Y. Takeda, and D. M. Greenberg. 1955. Chromatography of carboxylic acids on a silica gel column with benzene-ether solvent system. J. Biol. Chem. 212: 379.

26. Moore, S., and W. H. Stein. 1951. Chromatography of amino acids on sulfonated polystyrene resins. J. Biol. Chem. $192: 663$.

27. Evans, W. H., and M. L. Karnovsky. 1962. The biochemical basis of phagocytosis. Some aspects of carbohydrate metabolism during phagocytosis. Biochemistry. 1 : 159.

28. Mayer, M. M. 1961. Estimation of protein with folin-ciocalteau phenol reagent. In Experimental Immunochemistry. E. A. Kabat and M. M. Mayer, editors. Charles C Thomas, Publisher, Springfield. 556.

29. Atkinson, D. E. 1965. Biological feedback control at the molecular level. Science. 150: 851.

30. Beck, W. S., and W. H. Valentine. 1952. The aerobic carbohydrate metabolism of leukocytes in health and leukemia: Glycolysis and respiration. Cancer Res. 12: 818.

31. Chance, B. 1950. On the reaction of catalase peroxide with acceptors. J. Biol. Chem. 182: 649.

32. Theorell, H. 1951. The iron-containing enzymes. B. catalases and peroxidases. Hydro-peroxidases. In The Enzymes. J. B. Sumner and K. Myrback, editors. Academic Press, Inc., New York. 1st edition. 2 : 397. 
33. Paul, B., A. Mukherjee, R. J. McRipley, and A. J. Sbarra. 1967. Direct estimation of hydrogen peroxide in phagocytizing cells. Am. Soc. Microbiol. 92. (Abstr.)

34. Beck, W. S. 1958. Occurrance and control of the phosphogluconate oxidation pathway in normal and leukemic leukocytes. J. Biol. Chem. 232: 271.

35. Brin, M., and R. H. Yonemoto. 1958. Stimulation of the glucose oxidative pathway in human erythrocytes by methylene blue. J. Biol. Chem. 230 : 307.

36. Wenner, C. E. 1959 . Oxidation of reduced triphosphopyridine nucleotide by ascites tumor cells. $J$. Biol. Chem. 234: 2472.

37. Cagan, R. H., and M. L. Karnovsky. 1964. Enzymatic basis of the respiratory stimulation during phagocytosis. Nature. $204: 255$.

38. Rossi, F., and M. Zatti. 1964. Changes in the metabolic pattern of polymorphonuclear leukocytes during phagocytosis. Brit. J. Exptl. Pathol. 45 : 548.

39. Selvaraj, R. J., and A. J. Sbarra. 1966. Relationship of glycolytic and oxidative metabolism to particle entry and destruction in phagocytosing cells. Nature. $211: 1272$.

40. Malawista, S. E., and P. Bodel. 1967. The dissociation by colchicine of phagocytosis from increased oxygen consumption in human leukocytes. J. Clin. Invest. $46: 786$.

41. Karnovsky, M. L. 1962. Metabolic basis of phagocytic activity. Physiol. Rev. $42: 143$.

42. Rowley, D. 1962. Phagocytosis. Advan. Immunol. 2: 241.
43. Iyer, G. Y. N., and J. H. Quastel. 1963. NADPH and NADH oxidation by guinea pig polymorphonuclear leucocytes. 1963. Can. J. Biochem. Physiol. 41 : 427.

44. Roberts, J., and J. H. Quastel. 1964. Oxidation of reduced TPN by guinea pig polymorphonuclear leucocytes. Nature. 202: 85.

45. Rossi, F., and M. Zatti. 1964. Biochemical aspects of phagocytosis in polymorphonuclear leukocytes. $\mathrm{NADH}$ and NADPH oxidation by the granules of resting and phagocytizing cells. Experientia. 20: 21 .

46. Zatti, M., and F. Rossi. 1967. Mechanism of the respiratory stimulation in phargocytosing leukocytes. The $\mathrm{KCN}$-insensitive oxidation of NAD$\mathrm{PH}_{2}$. Experientia. 22 : 758.

47. Evans, W. H., and M. L. Karnovsky. 1961. A possible mechanism for the stimulation of some metabolic functions during phagocytosis. J. Biol. Chem. 236 : PC30.

48. Baehner, R. L., and D. G. Nathan. 1967. Leucocyte oxidase: Defective activity in chronic granulomatous disease. Science. 155: 835 .

49. Windhorst, D. B., B. Holmes, and R. A. Good. 1967. A newly defined X-linked trait in man with demonstration of the Lyon effect in carrier females. Lancet. 1 : 737.

50. Windhorst, D., P. Quie, B. Holmes, A. R. Page, and R. A. Good. The genetic definition of a newly described disease due to leukocyte malfunction. J. Clin. Invest. 46: 1133. (Abstr.) 